\title{
Vjerske teme usmenoknjiževnih i drugih zapisa Milana Bubanovića iz križevačkoga kraja
}

\author{
Tanja Baran*
}

\begin{abstract}
Sažetak
U ovom se radu kontekstualiziraju i analiziraju zapisi mladoga novinara, poliglota i kritičara Milana Bubanovića (pod pseudonimom Milan Dimitrev) iz križevačkoga kraja s naglaskom na usmenoknjiževne zapise $i$ vjerske teme koje se pojavljuju u tim zapisima. Cilj je ovoga istraživanja dokazati da su Križevci imali svojega predstavnika koji je zabilježio usmenoknjiževnu građu, ali i ostale sadržaje iz križevačke povijesti i suvremenosti, prema uputama Pitanja na sve priatelje domaćih starinah i jugoslavenske pověstnice, objavljenima u sredinom 19. stoljeća utemeljenom časopisu Arkiv za pověstnicu jugoslavensku, književnika i polihistora, prvoga predsjednika Matice hrvatske Ivana Kukuljevića Sakcinskoga. Bubanović je odgovorio na 12 od 26 postavljenih pitanja, u što je utkao $i$ nekoliko usmenoknjiževnih žanrova: prve zapise predaja, vjerovanja i izreke $u$ križevačkom kraju, od kojih su predaje vjerske tematike. Taj neveliki usmenoknjiževni korpus, kao i drugi zapisi, svjedoče o prožimanju usmene književnosti $i$ vjerskih sadržaja od davnina i u križevačkom kraju.
\end{abstract}

Ključne riječi: Milan Bubanović, Milan Dimitrev, Ivan Kukuljević Sakcinski, Križevci, usmena književnost, Arkiv

\section{Uvod}

Devetnaesto je stoljeće vrijeme najintenzivnijega prikupljanja usmenoknjiževne građe na cijelom hrvatskom prostoru. Najsnažnije su poticaje za bilježenje književne građe oblikovane u narodu, koja je dotada prenošena većinom usmenom predajom, tijekom 19. stoljeća dali najprije biskup Maksimilijan Vrhovac, pa Ivan Kukuljević Sakcinski, zatim Matica hrvatska i na kraju Odbor za narodni život i običaje današnje HAZU. Prema njihovim se objavljenim uputama intenzivno zapisivalo po cijeloj Hrvatskoj, što je u pravilu bilo uvjetovano buđenjem nacionalne svijesti za Hrvatskoga narodnoga preporoda.

* Dr. sc. Tanja Baran, Hrvatska radiotelevizija, Prisavlje 3, Zagreb, Hrvatska. E-adresa: tanja. baran@hrt.hr 
Križevci i križevački kraj dali su svoj odgovor na sve te poticaje tijekom 19. stoljeća u obliku usmenoknjiževnih zapisa. U tom je vremenu prikupljen sadržajan korpus od gotovo petnaest rukopisa, od kojih su neki nastali i bez ikakvih naputaka, prema osobnoj želji zapisivača za prikupljanjem križevačkoga narodnoga blaga. Uz tih petnaestak rukopisa posebno mjesto zauzimaju 1857. godine objavljeni Odgovori na njekoja pitanja Družtva za jugoslavensku povjestnicu i starine Milana Bubanovića, koji je pod pseudonimom Milan Dimitrev uz povijesne podatke o Križevcima dao i nešto usmenoknjiževnih zapisa (Bubanović, 1857). Bubanovićev prilog odgovor je na poziv Pitanja na sve priatelje domaćih starinah $i$ jugoslavenske pověstnice, koja je Ivan Kukuljević Sakcinski 1851. objavio u prvom broju novoosnovanoga časopisa Arkiv za pověstnicu jugoslavensku (Kukuljević Sakcinski, 1851). To Bubanovićevo opsegom neveliko gradivo prvi je zapis predaja i vjerovanja u križevačkom kraju.

Zanimljivo je da je većina ostalih zapisa nastala u križevačkoj okolici, a tek manjina u samom gradu Križevcima. Bubanović je kombinirao i same Križevce i križevačku okolicu. Te su zapise usmene književnosti ostvarili uglavnom obrazovani, a široj javnosti manje poznati ljudi koji su živjeli i radili u križevačkom kraju. Mladi Bubanović bio je novinar i kulturno-književni djelatnik. Jedan dio zapisa ostvarili su hrvatskoj javnosti dobro poznati kulturni radnici i književnici poput Ivana Kukuljevića Sakcinkoga, Đure Deželića i Franje Ksavera Kuhača, ali oni najčešće nisu ispisali točne lokalitete nastanka zapisa, nego su kao mjesto nastanka zapisa navodili Križevačku regimentu, granicu, županiju, krajinu ili križevački kraj, pa se ne može sigurno tvrditi da su ti zapisi nastali baš u današnjim granicama križevačkoga kraja ili u nekim drugim krajevima koji su u 19. stoljeću teritorijalno pripadali Križevačkoj pukovniji i Križevačkoj županiji.

Tih petnaestak rukopisa dosad su bili uglavnom nepoznati, a također slabo poznata objavljena križevačka usmenoknjiževna građa u 19. stoljeću dosad nije bila analizirana i kontekstualizirana. ${ }^{1}$ Pronalaskom i analizom rukopisa ${ }^{2}$ i objavljenih zapisa dokazano je da je dosad po usmenoj književnosti slabo poznat križevački kraj potpuno odgovorio na sve hrvatske usmenoknjiževne poticaje u 19. stoljeću.

\section{Ivan Kukuljević Sakcinski kao nadahnitelj Milanu Bubanoviću u prikupljanju usmenoknjiževne građe u križevačkom kraju}

Ivan Kukuljević Sakcinski potaknuo je križevačkoga mladoga talentiranoga novinara, kulturnoga i književnoga djelatnika, kritičara i poliglota Milana Bu-

1 Prvo cjelovito otkrivanje javnosti dosad nepoznatih rukopisa, kao i objavljene križevačke usmenoknjiževne građe, s kontekstualizacijom i analizom, objavljeno je u autoričinu doktorskom radu Usmenoknjiževno nasljeđe križevačkog kraja u kontekstu hrvatske književnosti 19. stoljeća (Baran, 2012). Taj je doktorski rad, pod mentorstvom Stipe Botice, obranjen na Odsjeku za kroatistiku Filozofskoga fakulteta Sveučilišta u Zagrebu 19. srpnja 2012. godine.

2 Većina se tih rukopisa čuva u Arhivu Odsjeka za etnologiju HAZU u Zagrebu te jedan dio u prijepisu Instituta za etnologiju i folkoristiku u Zagrebu. 
banovića na zapisivanje raznolikoga sadržaja iz prošlosti i sadašnjosti križevačkoga kraja, pa i usmene književnosti, ali je Sakcinski i prvi zapisivač križevačkih usmenih pjesama. Prvih dvanaest pjesama u kojima se spominje križevačko ime objavljeno je u iznimno važnoj zbirci Pěsme s dodatkom narodnih pěsamah puka hàrvatskoga Ivana Kukuljevića Sakcinskoga ${ }^{3}$ objavljenoj 1847. godine. Riječ je o jednoj od prvih cjelovitijih zbirki zapisa hrvatske usmene književnosti koje je prikupio taj poznati kulturni radnik u vremenu nakon Hrvatskoga narodnoga preporoda.

Kako je odrastao i stasao u preporodnom vremenu, družeći se s ključnim ljudima koji su oblikovali društvenu i kulturnu stvarnost toga doba, ne treba se čuditi Kukuljevićevu interesu za prikupljanje narodnoga blaga. On usmenu književnost nije zapisivao prema poticajima neke institucije, nego ga je na zapisivanje usmene književnosti potaknulo ozračje vremena u kojem je živio. Na zapisivanje usmene književnosti on je poticao druge. Kao predsjednik Matice hrvatske prvi je darovao zbirku narodnih pjesama Pjesme junačke i ženske, iz svih krajeva, naročito kajkavske ženske pjesme iz okoliša zagrebačkoga i Zagorja (Smičiklas i Marković, 1892, 54), nakon što je Matica 1877. godine uputila poziv na prikupljanje narodnih pjesama: »Prvi pokloni svoje ogromne zbirke predsjednik Ivan Kukuljević, što je sam sabrao i što je dobivao kroz dvadeset godina sa raznih strana kao predsjednik historičkoga društva. U ovom daru imade i krasna Tommaseova zbirka, koja imade osobito lijepih junačkih pjesama « (Smičiklas i Marković, 1892, 53-54).

Svoje ključne usmenoknjiževne doprinose Kukuljević je dao u Dodatku već spomenute zbirke njegovih vlastitih pjesama iz 1847. godine te objavom Pitanja Društva za jugoslavensku povjestnicu i starine utemeljenoga 1850. godine, među kojima je bilo i pitanja posvećenih usmenoj književnosti, a zatim i objavljivanjem tih odgovora u Arkivu za povjestnicu jugoslavensku. Križevački usmenoknjižev-

3 Ivan Kukuljević Sakcinski (Varaždin, 1816. - Puhakovec, 1889.), političar, književnik i polihistor. Godine 1837. upoznao je Ljudevita Gaja, koji ga je oduševio za ilirsku ideju. Kukuljević je počeo surađivati u Danici, u kojoj mu je odmah 1837. objavljena prva hrvatska pjesma. U vrijeme boravka u Beču 1840. pisao je pjesme i novele te niz djela na hrvatskom i njemačkom jeziku, koja su djelomice sačuvana ili izgubljena. Godine 1840. Kukuljević je bio premješten u Milano, gdje je za hrvatski jezik i književnost oduševio Petra Preradovića. Na vlastiti zahtjev 1842. napustio je vojnu službu i posvetio se kulturnopovijesnom istraživanju i politici. Bio je zastupnik u Hrvatskom saboru, u kojem je 2. svibnja 1843. održao prvi govor na hrvatskom jeziku. Zatim je 1845. imenovan velikim sucem Varaždinske županije, blisko je 1848. surađivao s banom Josipom Jelačićem, od godine 1861. bio je veliki župan Zagrebačke županije. Od 1851. do 1858. bio je predsjednik Matice ilirske, pa od 1874. do 1889. prvi predsjednik Matice hrvatske te počasni član JAZU (tek od 1886., jer je 1866. odbio imenovanje zbog neprimanja Ljudevita Gaja, Ivana Mažuranića, Dimitrija Demetra i Vjekoslava Babukića). Dopisivao se s europskim književnim, kulturnim i znanstvenim predvodnicima te bio član mnogih akademija. U svojim historiografskim i kulturnopovijesnim istraživanjima prikupio je građu bez koje se ne može zamisliti hrvatska pravna, politička i kulturna povijest. Kukuljević je bio iznimno popularan sredinom 19. stoljeća, zatim je dugo bio osporavan i interpretiran gotovo isključivo kao istraživač starina i kulturni povjesničar, a manje kao književnik. Godine 1850. s kolegama je osnovao Društvo za povjesnicu jugoslavensku, kojemu je bio predsjednik. Bio je i urednik Arkiva za povjesnicu jugoslavensku, koji je marljivo uređivao gotovo četvrtinu stoljeća, od 1851. do 1875. godine (Bogišić, 1998, s. v. Kukuljević; Deželić, 1925). 
ni korpus zastupljen je u oba Kukuljevićeva prinosa. Križevačkih pjesama ima i u Dodatku zbirke pjesama, a odgovore iz Križevaca na Kukuljevićeva pitanja iz Križevaca poslao je mladić Milan Bubanović pod pseudonimom Milan Dimitrev. Ti su odgovori i objavljeni u Arkivu 1857. godine. Iz perspektive križevačkih usmenoknjiževnih zapisa zanimljivo je da je Kukuljević još kao četrnaestogodišnjak 1830. godine posjetio najvjerojatnijega prvoga zapisivača najpoznatijih hrvatskih vinsko-pajdaških regula Križevački štatuti stenjevečkoga župnika Tomaša Mikloušića, koji je mladomu Sakcinskomu preporučio čitanje hrvatskih knjiga (Bogišić, 1998, s. v. Kukuljević). Objavom Bubanovićevih odgovora u Arkivu za povjestnicu jugoslavensku Križevci su dobili prvi objavljeni zapis posvećen raznim aspektima svojih dragocjenih starina i jedan od prvih zapisa usmene književnosti.

\section{Dosadašnja recepcija Bubanovićevih Odgovora}

Odgovori Milana Bubanovića (Križevci, 17. studenoga 1836. - Varaždin, 29. siječnja 1856.), objavljeni su na sedam stranica četvrte knjige Arkiva 1857. godine. Činjenica je da je Bubanović taj tekst napisao barem godinu dana ili dvije godine ranije jer je umro početkom 1856. godine, 29. siječnja (Vegh, 1998, 198-199). Osobito je zanimljivo da je tako mlada osoba koja je umrla s tek napunjenih 19 godina bila toliko obaviještena o Kukuljevićevim nastojanjima i da je između svih velikana križevačkoga kulturnoga života u 19. stoljeću odgovore u Arkiv poslao široj javnosti manje poznat mladić. No, kada se pogleda u Bubanovićev životopis, zadivljuje što je tako mlad čovjek u 19 godina života uspio napraviti i potiče na razmišljanje što bi tek stvorio da je poživio dulje.

Prema pisanju Rade Milosavljevića u Leksikonu Križevčana, Milan Bubanović osnovnu je školu završio u Križevcima, gimnaziju u Zagrebu, pravo u Grazu i Beču. Ističe da je bio talentirani novinar, poliglot i kritičar te da je objavio zbirku pjesama Vijenac zahvalnosti (Gradec, 1854.), prvu povijest Grkokatoličke biskupije u Križevcima na hrvatskom jeziku i životopis Marka Badovinca, te da je surađivao u periodici. Milosavljević ističe da je Bubanović napisao najzanimljiviji rad za Križevce objavljen pod naslovom Odgovor na nekoja pitanja Društva za jugoslavensku povjestnicu $i$ starine 1857. te da je često pisao pod pseudonimom Dimitrev, koji je uzeo po ocu Dimitriju, tajniku Križevačke i Varaždinske županije (Milosavljević, 1988, 25).

Željko Vegh u Leksikonu književnika u zborniku Križevačka književna slava piše da je Bubanović za svojega kratkoga života napisao vrlo mnogo, da je brojnim člancima u časopisu Neven upoznavao hrvatsku inteligenciju s važnijim kulturnim događajima u Europi jer da je znao nekoliko europskih jezika. U člancima objavljenim u Gospodarskim novinama, prema pisanju Željka Vegha, Bubanović je pisao o svilarstvu i pekarstvu u Križevcima te o križevačkom nazivlju za voće: jabuke, kruške i grožđe, a u Nevenu je objavio i članak o Križevačkoj biskupiji (Vegh, 1998, 198-199).

O Bubanovićevu je javljanju u Arkiv kratki spomen 1989. godine dao Rade Milosavljević u Bibliografiji radova o križevačkom kraju. Napisao je da "pored 
historijskih podataka o Križevcima i okolini, autor opisuje narodne običaje i vjerovanja« (Milosavljević, 1989, 101). Taj podatak nije potpuno točan jer u Bubanovićevim odgovorima nema opisa narodnih običaja. Olga Maruševski Bubanovićeve je odgovore imala u rukama jer je u radu Križevci u 19. stoljeću pobrojila glavne teme Bubanovićeva javljanja, ali ne spominjući Bubanovićev doprinos poznavanju križevačkoga usmenoknjiževnoga blaga. To je Bubanovićevo javljanje i kontekstualizirala u povijesne okolnosti sredine 19. stoljeća:

Politički je život u cijeloj zemlji zamro, pa se snage okreću znanosti. Hrvatska historiografija razvija se upravo u doba političke represije, dok je preporod kao odjek evropskog romantizma pobudio sam zanimanje za prošlost. Društvo za jugoslavensku povijesnicu i starine prikuplja građu, izrađuju se prve topografije, a dopisnik je iz Križevaca Milan Bubanović. On izvještava da su gornja vrata srušena 1852; zatim o fratarskom groblju, koje je otkriveno prilikom obnove biskupske rezidencije 1841., o biskupskoj knjižnici, o crkvi sv. Križa, gdje su sada smješteni kažnjenici, a služila je i kao konačište vojnim transportima; o slici na glavnom oltaru koju su pavlini bili prenijeli u svoj samostan. Spominje i crkvicu sv. Ulriha, što je narod zove sv. Vurij, i slike što su ondje bile smještene, za koje predmnijeva da su pripadale pavlinima (Maruševski, 1993, 58).

I Željko Vegh i Rade Milosavljević i Olga Maruševski tim su napisima pokazali da su upućeni u Bubanovićev rad za potrebe Arkiva, ali su u svojim opisima Bubanovićev sadržaj opisali tek djelomično, onoliko koliko je bilo dostatno za potrebe njihovih šire usmjerenih istraživanja i promišljanja. Iz ukupnosti njihovih napisa svejedno se može doznati o vrijednosti bogatoga Bubanovićeva rada.

\section{Bubanovićevi odgovori na Kukuljevićeva pitanja: materijalno $i$ duhovno u prožimanju}

Bubanovićevi su odgovori od 1857. javno dostupni jer su te godine objavljeni u Arkivu, koji je danas digitaliziran i tako lako dostupan zainteresiranim čitateljima. Pretisak Bubanovićevih odgovora pod nazivom Povjesnica $i$ starine napravila je Matica hrvatska Križevci te ga objavila u već spomenutoj knjizi Križevačka književna slava 1998. godine.

Sâm Bubanović već u naslovu teksta ističe da odgovara na samo neka pitanja Društva za povjesnicu jugoslavensku. Kukuljević ih je, naime, 1850. godine postavio 26, a zapisivače je na odgovaranje motivirao tako što je uz pitanja napisao da će se imena zapisivača sa zahvalnicom staviti u novine te da ce se pristigli sastavci čitati na velikoj skupštini Društva (Kukuljević Sakcinski, 1851, 241-243). U tom popratnom tekstu zamolio je da sastavljači odgovore na jedno ili na više postavljenih pitanja te da odgovore napišu na bilo kojem jeziku. Zato se Bubanović vjerojatno nije opterećivao time što nije odgovorio na sva pitanja. Odgovore je napisao na štokavskom narječju. Kukuljević je želio dobiti što cjelovitiju sliku hrvatskih krajeva pa je pitanja postavio tako da se po odgovorima mogao dobiti presjek povijesti i aktualnoga trenutka određenoga kraja u svim životnim područjima. Kombinirao je prikaz materijalne kulture koju je u Križevcima vidio 
i o kojoj je znao te prikaze duhovne baštine s naglaskom na usmenu književnost i ukupnost tradicijske kulture. Tako je Kukuljević pisao o reljefu, grobljima, arheološkim nalazima, o ostatcima starih gradova, utvrda, o materijalnim i pisanim dokumentima o toj građi, tražio je da se pojedini kraj opiše geografski, da se popišu i opišu znameniti objekti, umjetnine, arhivi i stari rukopisi. Osamnaesto je pitanje posvetio i radnim i godišnjim običajima u narodu te molbi za opis pjesama koje se pjevaju uz određeni običaj. Sljedeća tri pitanja posvetio je predajama, pričama te bajkama i pjesmama s naglaskom na mitološki sadržaj. Zasebno pitanje Kukuljević je postavio vezano uz sadržaj narodnih pjesama, zatim je pitao o znamenitim ljudima, starim grobovima s napisima i grbovima. Na kraju je postavio pitanje o tome bavi li se tko u kotaru popisivanjem starina i bi li se od te osobe mogla kupiti kakva umjetnina ili bi li se mogla dobiti na dar za narodni muzej.

Na ponajprije povijesna i etnografski usmjerena Kukuljevićeva pitanja Bubanović je odgovorio u lijepoj mjeri. Od postavljenih 26 pitanja, odgovorio je na 12, konkretno na 1., 2., 3., 4., 6., 8., 11., 12., 13., 14., 19. i 24. pitanje. Nakon uvodnih je rečenica, u kojima je i sâm napisao nekoliko redaka o važnosti prikupljanja povijesne građe, istaknuo da je odgovorio na pitanja o Križevcima onako kako je znao, čuo i vidio.

\section{Sadržaj Bubanovićevih Odgovora — prve zabilježene predaje, vjerovanja i izreke u križevačkom kraju}

U prvom odgovoru Bubanović je pisao o tadašnjim ostatcima križevačkoga gradskoga bedema, o nekadašnjoj podjeli grada na Gornji i Donji, o srednjovjekovnom gradskom uređenju, o Križevcima kao sjedištu vojne regimente, o rušenju gradskih vrata 1852. godine, o tada pronađenim novčićima u crkvi sv. Ladislava.

Drugi odgovor odnosi se na spomen križevačkoga grkokatoličkoga biskupskoga sjedišta, gdje je nekada bilo franjevačko groblje, na cara Leopolda II., koji je franjevačku crkvu i samostan darovao križevačkomu biskupu te na iskopane kosti, većem broju svećeničkih tijela, u sačuvanim ljesovima kada se 1841. popravljalo po gradu.

U trećem odgovoru obrazlaže da je to mjesto na kojem su sačuvane kosti bilo ograđeno običnom ogradom i da se na ljesove naišlo kada su se kopale jame za gašenje vapna. Zaključio je da je zapravo cijelo to dvorište bilo groblje te da je tom prilikom pronađeno razno prstenje. Čije je to prstenje i kako se tamo našlo, Bubanović nije znao objasniti.

Četvrti je njegov odgovor posvećen crkvi sv. Križa uz koju Bubanović spominje predaju o postanku najstarije križevačke crkve:

U Križevcih se nalazi na pol razorena crkva sv. Križa, s kojom je skopčana pripoviedka, da je jednoč u staro doba na onom mjestu njeka djevojka s vodom izvukla jedan krst, i da su to gradjani držali za božje objavljenje, te su vrhu onoga zdenca crkvu sagradili, nadievši joj ime sv. Križ, odkuda se je čitav grad nazvao Križevac. Nad tiem zdencem stoji veliki oltar, što se još i dan danas vidi (Bubanović, 1857, 192). 
Zatim pripovijeda da je sv. Križ bio župna crkva sve dok u nju nije udario grom i većim je dijelom razorio te da su poslije pavlini odredili da župna crkva bude uz njihov samostan, što je i danas. Ističe da su Križevčani u više navrata željeli obnoviti crkvu sv. Križa, ali nisu uspjeli jer je bila korištena za potrebe vojnoga transporta, a i da u njoj u najnovijem vremenu žive kažnjenici.

Kratki odgovor na šesto pitanje Bubanović je posvetio sažetomu opisu bunara koji je bio ispod glavnoga oltara crkve sv. Križa.

U osmom odgovoru govori se o starom, čak i rimskom novcu, koji je pronađen tijekom raskopavanja gradskih bedema. Misli da je rimske novčiće poslao nekadašnji vrhovni križevački župan za gradski muzej. Bubanović ističe i da je njegov otac, kada je gradio kuću, iskopao zemljani lončić s 268 nevrijednih srebrnih mađarskih novčića.

U odgovoru na jedanaesto pitanje opisuje tzv. Krajinske vrtove izvan Križevaca, selo Glogovnicu i istoimenu rijeku. Spominje se i bitke s Turcima iz 1561., koja se vodila uz rijeku Glogovnicu. Opisuje rijeku Korušku i crkvu Marije Koruške pokraj Križevaca, uz koju također donosi jednu predaju, odnosno legendu o čudu Majke Božje: »U toj se crkvi nalaze podosta velike i težke verige, za koje se pripovjeda, da su se jednoč za turskieh vremenah nekakvi robovi Marii Koruškoj pomolili, i da su im onda verige same s noguh pale, te onako sve do danas u crkvi ostale «(Bubanović, 1857, 193). Bubanović spominje i poljanu Vratno ispod kalničkih planina, dva sata udaljenu od Križevaca, na kojoj je sklopljen jedan hrvatsko-mađarski savezni ugovor.

Kalniku, pravoslavnomu manastiru Lepavina i templarskomu samostanu u Glogovnici posvećen je odgovor na dvanaesto pitanje. U njemu naglašava podjelu Kalnika na mali i veliki grad, a spominju se i narodne priče »da iz maloga u veliki grad podzemaljski put vodi, i da pred ulazom špilje novci cvatu « (Bubanović, 1857, 193-194). Bubanović je ispisao i dobro poznatu predaju o Crnoj Kraljici vezanu uz Kalnik i obližnji Grebengrad te obrazloženje stalnoga motiva Crne Kraljice, ponajprije u gradovima:

O Kalniku i o nedaleko od njega ležećem Grebengradu pripovieda narod, da u njima stanuje crna gospoja, i ova pričica, koja se skoro o svieh našieh gradovih pripovieda, mislim da se iz toga raztumačiti dade, što si je naš narod plemićke gradove predstavljao kao gniezdo svega zla, kojemu on robuje i služi. (?) - A mi znademo, da su stari Slaveni dva elementa častili, svietlost i tminu; svietlost (Bielbog) su smatrali za dobro, a tminu (Ćrnibog) za zlo, te upravo polag ovoga ostanka poganskieh vremenah izmislili su si u potonje doba, (kad je već kršćanstvo uvedeno bilo), crnu gospoju kao stvorenje, od koga sve zlo dolazi. I radi toga su ju nastanili u plemićke gradove, od kojieh su oni mnogo patili i mukah proživili. Dakako da je i crna gospoja mnogo puta i dobro činila, no to je bilo riedko, kao i kod tmine ili crnog boga (Bubanović, 1857, 194).

Bubanović zatim geografski u blizinu Koprivnice stavlja pravoslavni manastir Lepavinu, ispisuje povijest manastira, njegovu adimistrativnu pripadnost Pakračkoj eparhiji, govori da je uz manastir vezano 7 do 9 obitelji koje imaju lijepe povlastice prema kojima ne trebaju plaćati porez i davati mladiće za vojnike. Opisuje manastirske umjetnine, ističe da u njemu uz poglavara živi sedam redovnika 
te da im je glavna svetkovina Velike Gospoje. Na kraju toga poprilično velikoga odgovora opisuje selo Glogovnicu, u kojem je bio samostan templara, od kojega su ostale vidljive temeljne zidine. Ističe da je na glogovničkom groblju jedan jako velik kamen, koji je vjerojatno starodrevna grobnica te da ju planira iskopati kada dođe u to selo. Napisao je još i da je župna crkva bila vezana uz samostan, ali da je već četvrtinu stoljeća bez zvonika i da je pred rušenjem.

Trinaesti odgovor Bubanović je posvetio opisu kapele sv. Ulricha, što ga narod u Križevcima zove sv. Vurij, koja je smještena usred jedne šume na privatnom posjedu. Nabrojio je nazive četiri slike ispisane latinskim jezikom koje se čuvaju u crkvi, a za koje misli da su se prije morale čuvati u pavlinskom samostanu u Križevcima. Nabrojio je još nekoliko vrijednih slika koje je vidio u rezidenciji križevačkoga biskupa, u županijskom središtu u Križevcima, u gradskom arhivu te u sali gradske vijećnice. Po toj je zadnjoj slici, na kojoj je prikazan Ivan Zakmardi Dijankovečki, zaključio da je on utemeljio pavlinski samostan u Križevcima.

O starim rukopisima Bubanović piše u svojem četrnaestom odgovoru. Ističe da mu je jedan čovjek kazao da u knjižnici grkokatoličke biskupije ima grčkih i glagoljskih rukopisa te sâm priželjkuje da vidi ta knjižna bogatstva.

Dva prikupljena vjerovanja i jedna izreka sadržaj su devetnaestoga Bubanovićeva odgovora, a odnose se na vukodlaka i pticu pastirčicu te na črta:

Narod pripovieda o Vukodlaku toliko, da mrtvac zakopan u jamu, koja je preko noći izkopana stajala, postane vukodlakom. Za vukodlaka ubiti, drži narod za najbolje glogoviem ga trnom probosti. — Črt je poznat kod naroda kajkavskoga u phrasi, kada mati zločestomu dietetu reče: kaj me črtiš? t. j. zar si črt. — Izmedju pticah, koje naš narod u provincialu počituje, poznata mi je tako zvana pastiričica, koju svaki čovjek na svojem krovu nastanjenu imati želi, jer misli, da će mu sreću donieti (Bubanović, 1857, 196).

U posljednjem, opsegom najvećem dvadeset četvrtom odgovoru Bubanović piše o znamenitim muževima koji su umrli u Križevcima: o kiparu Marku Badovincu, o nekadašnjim križevačkim biskupima Silvestru Bubanoviću i Konstantinu Staniću te o križevačkom kanoniku Petru Štijiću. Zanimljivo je da je na kraju opisa radova Marka Badovinca Bubanović napisao da on osobno čuva Badovinčev kiparski autoportret i da će ga prvom prilikom poslati u muzej u Zagreb.

Zaključno Bubanović piše da će i o drugim krajevima, bude li prilike, na isti način zapisivati građu kao što je zapisao o Križevcima i okolici jer da je svjestan koristi takvih zapisa.

Iz Bubanovićevih odgovora mogu se doznati mnogi podatci o križevačkoj prošlosti, o administrativnom, vojnom i arhitektonskom uređenju grada, o organizaciji crkvenoga života, o nekim križevačkim crkvama te o arheološkim nalazima i grobljima. U tekstu je i opis nekih geografskih podataka, prirodnih ljepota, spominju se i određene povijesne prilike te znameniti Križevčani. Posebno mjesto pripada usmenoknjiževnoj građi jer je riječ o prvim zapisima predaja i vjerovanja iz križevačkoga kraja. 


\section{Zaključak}

Mladi, obrazovani i važnosti općega dobra svjestan Križevčanin Milan Bubanović na Kukuljevićeva je pitanja odgovorio polovično. Od 26 pitanja odgovorio je na 12. Na neka je pitanja odgovorio kratko, na neka opširno. Kada se konzultiraju znanstvene spoznaje o križevačkoj prošlosti, dolazi se do zaključka da je neupitna točnost Bubanovićevih podataka. U korpus uglavnom povijesnih podataka o Križevcima i okolici mladi je zapisivač utkao i nekoliko usmenoknjiževnih žanrova. Zapisao je tri predaje, četiri vjerovanja i jednu izreku. Prva je predaja posvećena postanku crkve sv. Križa, druga čudu Majke Božje u crkvi u Koruškoj, a treća Crnoj Kraljici na Kalniku. Vjerovanja su vezana uz Kalnik, na kojem iz maloga u veliki grad vodi podzemni put i pred ulazom u špilju cvatu novci, zatim uz vukodlaka i pticu pastirčicu, a izreka govori o črtu. Predaje i vjerovanja vezana uz Kalnik Bubanović je ugradio u odgovore u kojima daje povijesne podatke, a vjerovanja o vukodlaku, pastirčicu i izreku o črtu ispisao je u zasebnom odgovoru.

Životnost i zanimljivost odgovorima daje unošenje piščevih osobnih podataka u tekst ili planova za njegov osobni angažman. To se odnosi na pisanje o tome kako je i njegov otac u svojem dvorištu našao bezvrijedne srebrne mađarske novčiće, o tome kako sâm planira iskopati nadgrobni spomenik u Glogovnici, kako bi želio vidjeti rukopise u grkokatoličkoj knjižnici te o tome kako on osobno čuva kip, autoportret kipara Marka Badovinca, koji planira poslati u narodni muzej u Zagreb.

Na kraju iznosi plan da će odgovore na Kukuljevićeva pitanja prema mogućnostima potražiti i u ostalim sredinama, pa ne treba čuditi komentar uredništva Arkiva na početku Bubanovićeva teksta. Oni su, naime, uz njegov pseudonim Milan Dimitrev, u bilješci naznačili da je taj mladić, na žalost, umro te godine u Varaždinu (Bubanović, 1857, 191). Žalostan završetak mladoga života koji je svojim kratkotrajnim vrijednim radom, a ponajprije svojim Odgovorima, sredinom 19. stoljeća zadužio Križevce i križevački kraj.

\section{Literatura:}

Baran, Tanja (2012). Usmenoknjiževno nasljeđe križevačkoga kraja u kontekstu hrvatske književnosti 19. stoljeća (Doktorski rad). Filozofski fakultet Sveučilišta u Zagrebu.

Bogišić, Vlaho (ur.) (1998). Ivan Kukuljević Sakcinski. U: Vlaho Bogišić (ur.), Leksikon hrvatske književnosti (str. 187-189). Zagreb: Naprijed.

Bubanović, Milan (1857). Odgovori na njekoja pitanja Družtva za jugoslavensku povjestnicu i starine: Od Milana Dimitreva. Arkiv za povjestnicu jugoslavensku, 4, 191-199.

Deželić, Velimir (1925). Kukuljević Sakcinski pl. Božidar. U: Emilij Laszowski (ur.), Znameniti i zaslužni Hrvati te pomena vrijedna lica u hrvatskoj povijesti od 925-1925 (str. 152-153). Zagreb: Odbor za izdanje knjige.

Kukuljević Sakcinski, Ivan (1847). Pěsme s dodatkom narodnih pěsamah puka hàrvatskoga. Zagreb: Tiskom kr. pov. ilir. n. tiskarne Dra Ljudevita Gaja.

Kukuljević Sakcinski, Ivan (1851). Pitanja na sve priatelje domaćih starinah i jugoslavenske pověstnice. Arkiv za pověstnicu jugoslavensku, 1, 241-243. 
Maruševski, Olga (1993). Križevci u 19. stoljeću. U: Križevci: Grad i okolica (Umjetnička topografija Hrvatske). Zagreb: Institut za povijest umjetnosti Sveučilišta u Zagrebu.

Milosavljević, Rade (1988). Leksikon Križevčana. Križevci: Povijesno društvo Koprivnica.

Milosavljević, Rade (1989). Bibliografija radova o križevačkom kraju. Križevci: Gradska knjižnica Križevci.

Smičiklas, Tade; Marković, Franjo (1892). Spomen-knjiga Matice hrvatske od godine 1842. do godine 1892. Zagreb: Matica hrvatska.

Vegh, Željko (1998). Leksikon književnika. Stjepan Sučić (ur.), Križevačka književna slava: Hrvatska riječ u Križevcima. Križevci: Matica hrvatska.

Religious Topics in Oral Literature and Other Records Records of the Križevci Area by Milan Bubanović (Milan Dimitrev)

Tanja Baran*

\section{Summary}

In this paper the author contextualizes and analyses the records of the young journalist, polyglot and critic, Milan Bubanović (under the pseudonym of Milan Dimitrev) from the Križevci area with an emphasis on oral and religious topics in the said records. The aim of this study is to prove that the city of Križevci had its proper spokesman who recorded oral literature texts as well as other historical and contemporary topics having to do with Križevci, according to the instructions in the Pitanja na sve priatelje domaćih starinah i jugoslavenske pověstnice taken from the Arkiv za pověstnicu jugoslavensku established in the middle of the 19th century by writer and polyhistorian and first president of Matica hrvatska, Ivan Kukuljević Sakcinski. Bubanovic responded to twelve of the twenty-six questions asked by incorporating elements from several genres of oral literature — traditions and beliefs - most of them religious topics. These are the first records of the traditions, beliefs and adages (sayings) of the Križevci area. The body of oral literature recorded testifies to the fact that their oral literature was permeated by religious content even since ancient times. In his descriptions of history and of his own time, Bubanovic presents much data related to the Church, namely, on the Greek Catholic Eparchy, religious orders, churches, sacred monuments, works of sacred art and renowned ecclesiastical personages of the Križevci area.

Key words: collected oral literature, genres, religious subjects, Ivan Kukuljević Sakcinski, Arkiv, Milan Bubanović (Milan Dimitrev)

* Tanja Baran, Ph.D., Croatian Radiotelevision. Address: Prisavlje 3, 10000 Zagreb, Croatia. E-mail: tanja.baran@hrt.hr 